\title{
Characterisation and application of a murine monoclonal antibody specific for the serogroup $\mathrm{C}_{2}$ Salmonella
}

\author{
J. M. C. LUK, K. H. CHAN, R. S. W. TSANG and M. H. NG
}

\section{Department of Microbiology, University of Hong Kong, Hong Kong}

Summary. An $\mathrm{IgG}_{3}$ murine monoclonal antibody (designated MO8) specific for the serogroup $\mathrm{C}_{2}$ Salmonella lipopolysaccharide (LPS) was generated by fusing mouse myeloma cells NS1 with spleen cells of BALB/c mice immunised with heat-killed $S$. manhattan. MO8 reacted with purified LPS prepared from serogroup $\mathrm{C}_{2}$ Salmonella but did not react with that prepared from other $\mathrm{O}$ serogroups, and its reactivity was also specifically absorbed by serogroup $\mathrm{C}_{2}$ Salmonella only. Polyacrylamide gel electrophoresis of the serogroup $\mathrm{C}_{2}$ LPS and subsequent immunoblotting with MO8 yielded multiple reactive bands giving a characteristic ladder pattern. The specificity of MO8 was further demonstrated in the slide agglutination test with 223 bacteria, of which only 25 belonging to serogroup $\mathrm{C}_{2}$ Salmonella reacted with the MO8 ascitic fluid. The specificity of MO8 makes it useful not only for the serological identification of Salmonella but also for the epitope analysis of the serogroup $\mathrm{C}_{2}$ LPS.

\section{Introduction}

Routine laboratory diagnosis of salmonellosis depends on isolation of the causative organisms and confirmation of their identity by biochemical and serological methods (Edwards and Ewing, 1972; Kauffman, 1972). Serological identification of salmonellae rests on the detection of specific $\mathrm{O}$ (lipopolysaccharide of the cell envelope) and $\mathrm{H}$ (flagella protein) antigens according to the Kauffman-White scheme (Edwards and Ewing, 1972; Kauffman, 1972). Conventional monospecific antisera to the $\mathrm{O}$ antigens are raised in rabbits by immunisation with whole bacterial cells and unwanted cross-reacting antibodies are removed by absorption with related bacteria. However, this procedure is cumbersome, and incomplete absorptions and batch-to-batch variations between antisera are inevitable. Currently two alternatives for the production of $\mathrm{O}$-factor specific antibodies are available - one by raising antisera against synthetic antigenic determinants coupled to carrier molecules (Svenson and Lindberg, 1978); the other by raising monoclonal antibodies (MoAbs) against the specific factor of Salmonella lipopolysaccharides (LPS). The

Received 26 Jun. 1987; accepted 29 Sep. 1987.

Correspondence should be sent to: Professor $\mathrm{M} . \mathrm{H} . \mathrm{Ng}$, Department of Microbiology, University of Hong Kong, Northcote Science Building, 87 Pokfulam Road, Hong Kong. latter method has the advantage that virtually unlimited amounts of antibodies of the same specificity are available. Being truly monospecific, these MoAbs may also be useful for the mapping and recognition of potentially important antigenic epitopes in the serologically complex LPS molecules. One such epitope, not recognised previously by the conventional polyclonal antisera, has recently been described and characterised by us with MoAbs (Tsang et al., 1987). We now report the production and characterisation of $\mathrm{a} \mathrm{MoAb}$ against $S$. manhattan. The reactive epitope of the MoAb is discussed and its potential application for replacing the conventional O-factor specific polyclonal antisera is demonstrated.

\section{Materials and methods}

\section{Bacteria and preparation of lipopolysaccharides}

Salmonella paratyphi A (NCTC 5784) was obtained from the National Collection of Type Cultures, Colindale, England, and S. typhi 620Ty was a gift from B. A. D. Stocker, Department of Medical Microbiology, Stanford University Medical School, Stanford, CA, USA. All other bacteria were clinical isolates (from either blood or stool) obtained from the Clinical Microbiology Laboratory of Queen Mary Hospital, Hong Kong; and they were identified by standard biochemical and serological methods (Lennette et al., 1985). Isolates were grown on blood 
agar and in brain-heart infusion broth (Oxoid Ltd., London, England) at $37^{\circ} \mathrm{C}$ for 16 to 18 hours. Purified LPS was extracted from smooth strains by the hot phenolwater method of Westphal and Jann (1965).

\section{Production and characterisation of monoclonal antibodies}

BALB/c mice were inoculated intraperitoneally (i.p.) with $10^{8}$ heat-killed $S$. manhattan cells suspended in phosphate-buffered saline (PBS) $\mathrm{pH} \mathrm{7.5}$. Injections of similar doses were repeated on days 10,24 and 38. Four days after the last booster, $10^{8}$ spleen cells from a mouse that gave the highest antibody response to the immunising strain were fused with $10^{7} \mathrm{NS1}$ myeloma cells, with polyethylene glycol (PEG, mol. wt 4000 ; BDH, Poole) as the fusing agent (Köhler and Milstein, 1975). Hybridomas were screened for production of antibodies against $S$. manhattan by an enzyme-linked immunosorbent assay (ELISA), and those that produced specific antibodies were cloned twice by limiting dilution. Purified hybridomas were then injected i.p. into mineral oil-primed mice for the production of ascitic fluid. MoAbs were purified from the ascitic fluid by precipitation with ammonium sulphate $50 \%$ and their isotypes were determined by double immunodiffusion with mouse monoclonal antibody typing kit MMT 01K (Serotec, England).

\section{ELISA technique}

Serum antibodies from immunised mice and hybridoma monoclonal antibodies from culture supernate or mouse ascitic fluid were detected by the ELISA technique of Engvall and Perlman (1972). Microtitration plates (Immulon II, Dynatech Laboratories, Inc., Alexandria, VA, USA) were coated with $0.1 \mathrm{ml}$ of bacterial antigens (sonic lysates were used at a concentration of $10 \mathrm{mg} / \mathrm{L}$ and purified LPS at a concentration of $5 \mathrm{mg} / \mathrm{L}$ ) diluted in $50 \mathrm{~mm}$ bicarbonate buffer ( $\mathrm{pH} \mathrm{9.6)}$ at $4^{\circ} \mathrm{C}$ overnight. Sonic lysates were prepared from the bacteria listed in table I by the method of Hughes et al. (1971), and purified LPS was prepared from salmonellae of serogroups A ( $S$. paratyphi $A)$, B ( $S$. typhimurium), $C_{1}(S$. birkenhead $), \mathrm{C}_{2}$ (S. manhattan), D (S. typhi), $\mathrm{E}_{1}$ (S. newlands), and L ( $S$. minnesota). Unsaturated binding sites in the wells were blocked with bovine serum albumin (BSA) $2 \%$ in PBS. MoAbs in culture supernates or ascitic fluid $\left(10^{3}\right.$ dilution) were added to antigen-coated wells and the plate was incubated at $37^{\circ} \mathrm{C}$ for $90 \mathrm{~min}$. After three washes with PBS containing Tween $200.05 \%$ (PBS-Tween), peroxidase-conjugated goat anti-mouse IgG (Tago, Inc., Burlingame, CA, USA) diluted 1 in 1000 in BSA-PBS $1 \%$ was added and the plate was again incubated at $37^{\circ} \mathrm{C}$ for $90 \mathrm{~min}$. After four further washes with PBS-Tween, $O$ phenylenediamine (Sigma, St Louis, MO, USA) was added as substrate and the absorbance at $492 \mathrm{~nm}$ was measured after incubation for $30 \mathrm{~min}$ at $37^{\circ} \mathrm{C}$.

In the competitive-ELISA, $50 \mu \mathrm{l}$ of a $10^{6}$ dilution of the MO8 ascitic fluid was added with an equal volume of competing antibody (various dilutions of rabbit monospecific Salmonella agglutinating sera purchased from Wellcome Research Laboratories, Beckenham) to microtitration wells coated with a limiting concentration $(0.3 \mathrm{mg} / \mathrm{L})$ of the purified $S$. manhattan LPS. The incubation, washing and development procedures were as described above. The choice of concentrations of the solid phase antigen and the MoAbs had been determined previously in titrations designed to yield an optimal condition for detecting competition.

\section{Whole-cell radioimmunoassay (RIA) and dot-blot $R I A$}

A study of the binding of MoAb to bacterial cells or antigens adsorbed on to nitrocellulose (NC) paper was performed by procedures described previously (Tsang $e t$ al., 1987).

\section{Absorption of monoclonal antibody with bacteria}

Bacterial suspensions $\left(10^{12}\right.$ cells in $0 \cdot 2 \mathrm{ml}$ of PBS $)$ were prepared from each of the following bacteria: $S$. birkenhead (serogroup $\mathrm{C}_{1}$ ), S. manhattan (serogroup $\mathrm{C}_{2}$ ), and $P$ seudomonas aeruginosa. Each individual cell suspension was then mixed with an equal volume of a $10^{2}$ dilution of MO8 ascitic fluid and incubated at $4^{\circ} \mathrm{C}$ overnight. After depositing the bacterial cells by centrifugation, the serum was absorbed a second time for $2 \mathrm{~h}$ at $37^{\circ} \mathrm{C}$. The serum after each absorption was tested for residual antibody activity by dot-blot RIA against purified $S$. manhattan LPS.

\section{Polyacrylamide gel electrophoresis and immunoblotting}

LPS extracts were prepared by protease $K$ digestion of whole cell lysates, and separated on polyacrylamide gels, by the method of Hitchcock and Brown (1983). The resolved LPS components were stained by the method of Tsai and Frasch (1982). For immunoblotting, the separated LPS components were transblotted on to nitrocellulose paper (Schleicher and Schull, Dassel, FRG) following the procedure of Towbin et al. (1979). After electrotransfer, the NC paper was blocked with gelatin $3 \%$ in PBS and then incubated with MoAb in culture supernate for $2 \mathrm{~h}$ at $37^{\circ} \mathrm{C}$. After three washes in PBSTween, the MoAb attached to the NC paper was detected with ${ }^{125}$ I-labelled protein A and autoradiography. Labelling of the Staphylococcal protein A (Sigma, St Louis, MO, USA) was done by the method of Greenwood et al. (1963).

\section{Results}

Murine MoAbs were raised against a serogroup $\mathrm{C}_{2}$ Salmonella, $S$. manhattan, by the standard cell fusion technique, and the resulting hybridoma MoAbs were tested by ELISA against a panel of 
bacterial sonic lysates for preliminary specificity characterisation. One of the MoAbs thus obtained and designated as MO8, was found to react selectively with $S$. manhattan only, but not with any of the other bacteria tested (table I). MO8 was an $\mathrm{IgG}_{3}$ antibody with lambda light chains.

In addition to reaction with the immunising strain, MO8 was also found to bind to the cell surfaces of 11 different isolates of serogroup $C_{2}$ Salmonella in a radioimmunoassay. The amount of MO8 MoAbs bound by the serogroup $\mathrm{C}_{2}$ salmonellae was represented by the amount of ${ }^{125}$ I-labelled protein A attached to the cells and was in the range $8434 \mathrm{cpm}$ to $16452 \mathrm{cpm}$ (mean $10634 \mathrm{cpm}$; S.D. $2745 \mathrm{cpm}$ ). In contrast, MO8 MoAbs were not taken up by nine different serogroup $\mathrm{C}_{1}$ salmonellae; the average radioactivity bound was $130 \mathrm{cpm} \pm$ $41 \mathrm{cpm}$ (SD). Moreover the MO8 MoAbs were specifically removed by absorption with serogroup $\mathrm{C}_{2}$ salmonellae only, but not with serogroup $\mathrm{C}_{1}$ salmonellae nor with $P$. aeruginosa.

The reactivity of MO8 with purified LPS prepared from salmonellae of serogroups $A, B, C_{1}, C_{2}$, $D, E_{1}$, and $L$ was studied by ELISA, and only LPS from $S$. manhattan (serogroup $\mathrm{C}_{2}$ ), and not that from other $\mathrm{O}$ serogroups, was found to react with MO8. When subjected to polyacrylamide gel electrophoresis, the LPS from $S$. manhattan was separated into multiple bands, each differing from the next by a small increment in molecular weight and thus giving rise to a ladder pattern (fig. 1, lane

Table I. ELISA reactivity of MO8 with bacterial lysates

\begin{tabular}{lc}
\hline \multicolumn{1}{c}{ Bacterial lysates } & $\begin{array}{c}\text { Absorbance at 492 nm } \\
\text { in ELISA* }\end{array}$ \\
\hline Salmonella & \\
S. paratyphi-A (serogroup A) & $<0.05$ \\
S. typhimurium (serogroup B) & $<0.05$ \\
S. birkenhead (serogroup $C_{1}$ ) & $<0.05$ \\
S. manhattan (serogroup $\mathrm{C}_{2}$ ) & 1.09 \\
S. typhi $620 T y$ (serogroup D) & $<0.05$ \\
S. newlands (serogroup $\mathrm{E}_{1}$ ) & $<0.05$ \\
Escherichia coli & $<0.05$ \\
Shigella flexneri & $<0.05$ \\
Citrobacter freundii & 0.06 \\
Enterobacter aerogenes & $<0.05$ \\
Proteus mirabilis & $<0.05$ \\
Klebsiella pneumoniae & $<0.05$ \\
Serratia marcescens & $<0.05$ \\
Yersinia enterocolitica & $<0.05$ \\
Acinetobacter anitratus & $<0.05$ \\
Pseudomonas aeruginosa & $<0.05$ \\
Staphylococcus aureus & $<0.05$ \\
Streptococcus viridans & $<0.05$ \\
\hline
\end{tabular}

- Mean of two determinations.

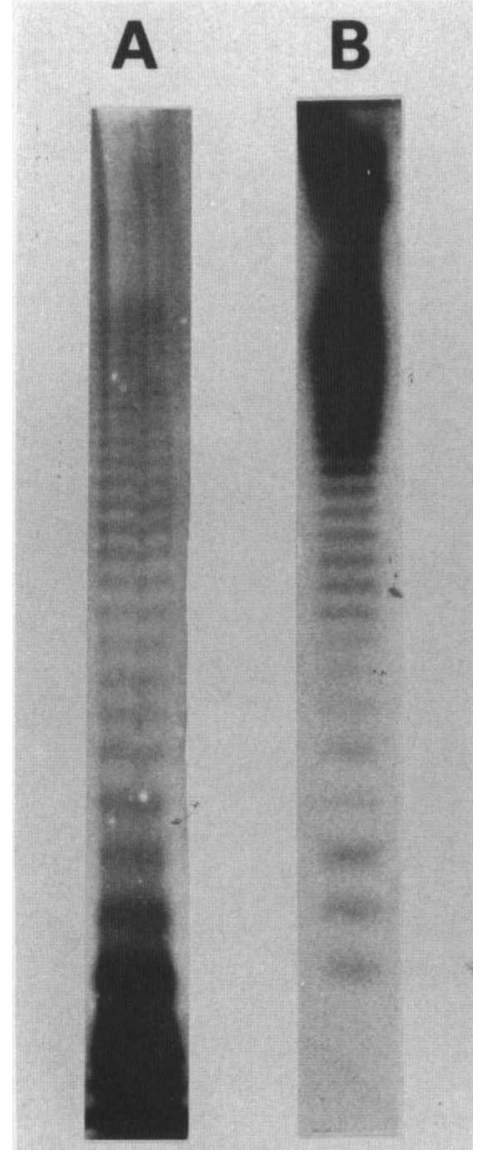

Fig. 1. Silver staining (A) and immunoblotting with MO8(B) of LPS from $S$. manhattan separated by polyacrylamide gel.

A). By immunoblotting, MO8 was shown to react against almost all species of the highly heterogeneous population of LPS molecules with the higher mol. wt species showing a stronger immunological reactivity with MO8 than those of lower molecular weight (fig. 1, lane B).

To investigate further the specificity of MO8, its reactivity with the $S$. manhattan LPS was compared with its reactivity with the conventional $O$ factor specific antisera by competitive ELISA (table II). The anti-O8 antiserum, but not the anti-O4 serum, was found to block the binding of MO8 to $S$. manhattan LPS. However, effective blocking was also obtained with an antiserum against $O$ factors 6 and 7.

To study the potential application of MO8 for the serological identification of serogroup $\mathrm{C}_{2}$ Salmonella, mouse ascitic fluid containing MO8 was used in a slide agglutination test with 154 strains of Salmonella species (143 serotypes from the most commonly encountered serogroups $A$ to $E$ 
Table II. Competition between MoAb MO8 and conventional polyclonal $\mathrm{O}$ antisera for binding to $S$. manhattan LPS as detected by ELISA

\begin{tabular}{ccc}
$\begin{array}{c}\text { Competing antiserum } \\
\text { (Dilution) }\end{array}$ & $\begin{array}{c}\text { Absorbance at } 492 \mathrm{~nm} \\
\text { in ELISA* }\end{array}$ & \% inhibition \\
\hline None & 0.514 & \\
Anti-O:4 & & 10 \\
1 in 10 & 0.458 & 3 \\
1 in 50 & 0.512 & 0 \\
1 in 100 & 0.556 & 0 \\
1 in 200 & 0.542 & \\
Anti-O:8 & & 65 \\
1 in 10 & 0.178 & 38 \\
1 in 50 & 0.316 & 29 \\
1 in 100 & 0.362 & 19 \\
1 in 200 & 0.411 & \\
Anti-O:6 \& & & 81 \\
1 in 10 & 0.095 & 65 \\
1 in 50 & 0.176 & 49 \\
1 in 100 & 0.262 & 38 \\
1 in 200 & 0.316 & \\
\hline
\end{tabular}

* Mean of four determinations.

and 11 from serogroups $\mathrm{G}, \mathrm{N}, \mathrm{O}$ and $\mathrm{R}$ ) and 69 strains of nine other species of bacteria (Enterobacteria, Acinetobacter anitratus, $P$. aeruginosa and Staphylococcus aureus). All 25 strains of Salmonella belonging to serogroup $C_{2}$ and one, belonging to serogroup $\mathrm{C}_{3}$, were agglutinated strongly and rapidly with the MO8 ascitic fluid, whereas all the other salmonellae and other bacterial species gave negative results in the slide agglutination test. This result was comparable with that obtained with a commercially available rabbit anti-Salmonella $\mathrm{O} 8$ serum.

\section{Discussion}

The murine MoAb, MO8, is believed to be specific for the $\mathrm{O}$-antigenic polysaccharide side chain of the serogroup $\mathrm{C}_{2}$ Salmonella because: (1) MO8 reacted with cell surface antigens from all 25 different strains of serogroup $\mathrm{C}_{2}$ salmonellae but did not react with any of the 22 serogroup $C_{1}$ salmonellae; (2) MO8 reacted with purified LPS prepared from serogroup $\mathrm{C}_{2}$ Salmonella but did not react with that prepared from serogroups $A, B, C_{1}$, $D, E_{1}$, and $L ;(3)$ the reactivity of MO8 with the serogroup $C_{2}$ LPS appeared to correlate with the relative abundance of the $\mathrm{O}$-specific side chain so that the antibody reacted more strongly with the higher mol. wt species of LPS than with the lower mol. wt species (fig. 1, lane B) (Jann et al., 1975; Goldman and Leive, 1980).

The $O$ polysaccharide side chains of the LPS of serogroups $\mathrm{C}_{1}$ and $\mathrm{C}_{2}$ Salmonella are antigenically related in that they share a common antigenic determinant of $\mathrm{O}$ factor 6 which is believed to correspond structurally to the disaccharide Dglucose $\rightarrow$ D-mannose (Fuller and Staub, 1968). Because MO8 is absorbed specifically by serogroup $\mathrm{C}_{2}$ organisms only and not by serogroup $\mathrm{C}_{1}$ organisms, this excludes $O$ factor 6 as the determinant recognised by MO8. Organisms in serogroups $\mathrm{C}_{2}$ and $\mathrm{C}_{3}$ possess an unique antigenic determinant of $\mathrm{O}$ factor 8 which distinguishes these organisms from the other salmonellae. Therefore it would seem likely that the antigenic specificity of MO8 may correspond wholly or partly to the disaccharide residues of $\mathrm{O}$ factor 8 , i.e., abequose $\rightarrow \mathrm{L}$-rhamnose (Svenungsson and Lindberg, 1979). On the other hand the subunit structures of the main polysaccharide side chains of serogroups $C_{1}$ and $C_{2}$ organisms are also different (Lindberg and Le Minor, 1984) which may well impart serological specificities to these two serogroups of salmonellae. The present data do not exclude the possibility that MO8 may recognise such structural differences. The inhibition of MO8 binding to serogroup $\mathrm{C}_{2}$ LPS by the monospecific antiserum raised against serogroup $C_{1}$ organisms $(O 6,7)$ may be explained by steric hindrance due to binding of antibodies to $O$ factor 6 because of its close proximity to the antigenic epitope recognised by MO8.

Despite the lack of definite data on the reactive epitope of MoAb MO8, its specificity for the serogroup $\mathrm{C}_{2}$ and possibly $\mathrm{C}_{3}$ salmonellae is substantiated by its positive slide agglutination reaction with all 25 serogroup $\mathrm{C}_{2}$ and one serotype $\mathrm{C}_{3}$ salmonellae and the negative result obtained with 197 other bacteria tested. The agglutinating ability of MO8 also makes it a potentially useful reagent compared with the conventional polyclonal factor-specific antiserum for the serological identification of salmonellae. MoAbs offer the advantages of being readily available and having well-defined specificities. As such, they are expected not only to enable reliable identification of this group of important human pathogens but also to be applicable in some of the proposed rapid immunological procedures for the direct detection of specific antigens in specimens or after growth enrichment in selective media (Sperber and Deibel, 1969; Gibbs et al., 1972; Sauborn et al., 1980). 


\section{REFERENCES}

Edwards P R, Ewing W H 1972 Identification of Enterobacteriaceae. Burgess, Minneapolis.

Engvall E, Perlmann P 1972 Enzyme-linked immunosorbent assay ELISA. III. Quantitation of specific antibodies by enzyme-labelled anti-immunoglobulin in antigen-coated tubes. Journal of Immunology 109: 129-135.

Fuller N A, Staub A M 1968 Immunochemical studies on Salmonella. 13: Chemical changes appearing on the specific oligosaccharide of $S$. chloeraesuis $\left(6-\mathrm{b}_{2}, 7\right)$ after its conversion by phage 14(6,7). European Journal of Biochemistry 4 : 286-300.

Gibbs P A, Patterson J T, Murray J G 1972 The fluorescent antibody technique for the detection of Salmonella in routine use. Journal of Applied Bacteriology 35: 405-413.

Goldman R C, Leive L 1980 Heterogeneity of antigenic-sidechain length in lipopolysaccharide from Escherichia coli O111 and Salmonella typhimurium LT2. European Journal of Biochemistry 107: 145-153.

Greenwood F C, Hunter W M, Glover J S 1963 The preparation of ${ }^{131}$ I labelled human growth hormone of high specific radioactivity. Journal of Biochemistry 89: 114-123.

Hitchcock P J, Brown T M 1983 Morphological heterogeneity among Salmonella lipopolysaccharide chemotypes in silverstained polyacrylamide gels. Journal of Bacteriology 154: 269-277.

Hughes D E, Wimpenny J W T, Lloyd D 1971 The disintegration of microorganisms. In: Norris J R and Ribbon D E (ed) Methods in Microbiology, Vol. 5B, Academic Press, London, pp 27-30.

Jann B, Reske K, Jann K 1975 Heterogeneity of lipopolysaccharides. Analysis of polysaccharide chain lengths by sodium dodecylsulfate polyacrylamide gel electrophoresis. European Journal of Biochemistry 60: 239-246.

Kauffman F 1972 Serological diagnosis of Salmonella species. Kaufmann-White Scheme. Munksgaard, Copenhagen.

Kohler G, Milstein C 1975 Continuous cultures of fused cells secreting antibody of predefined specificity. Nature 256: 495-497.
Lennette E H, Balows A, Hausler W J, Shadomy H J 1985 Manual of clinical microbiology, 4th edn. American Society for Microbiology, Washington DC.

Lindberg A A, Le Minor L 1984 Serology of Salmonella. In: Bergan T, Norris J R (eds) Methods in microbiology, vol. 15. Academic Press, London, p 5.

Sanborn W R, Lesmana M, Edwards E A 1980 Enrichment culture coagglutination test for rapid low-cost diagnosis of Salmonellosis. Journal of Clinical Microbiology 12: 151-155.

Sperber W H, Deibel R H 1969 Accelerated procedure for Salmonella detection in dried foods and feeds involving only broth cultures and serological reactions. Applied Microbiology 17: 533-539.

Svenson S B, Lindberg A A 1978 Immunochemistry of Salmonella O-antigens: preparation of an octasaccharide-bovine serum albumin immunogen representative of Salmonella serogroup $\mathrm{B} \mathrm{O}$-antigen and characterization of the antibody response. Journal of Immunology 120: 1750-1757.

Svenungsson B, Lindberg A A 1979 Diagnosis of Salmonella bacteria : antibodies against synthetic Salmonella O-antigen 8 for immunofluorescence and co-agglutination using sensitized protein A-containing staphylococci. Acta Pathologica et Microbiologica Scandinavica Section B 87 : 29-36.

Towbin H T, Staehelin T, Gordon J 1979 Electrophoretic transfer of proteins from polyacrylamide gels to nitrocellulose sheets: procedure and some applications. Proceedings of the National Academy of Sciences of the USA 76: 43504354.

Tsai C-M, Frasch C E 1982 A sensitive silver stain for detecting lipopolysaccharides in polyacrylamide gels. Analytical Biochemistry 119: 115-119.

Tsang $\mathrm{R} \mathrm{S} \mathrm{W,} \mathrm{Chan} \mathrm{K} \mathrm{H}$, Chau P Y, Wan $\mathrm{K} \mathrm{C}, \mathrm{Ng} \mathrm{M} \mathrm{H}$, Schlecht $S 1987$ A murine monoclonal antibody specific for the outer core oligosaccharide of Salmonella lipopolysaccharide. Infection and Immunity 55: 211-216.

Westphal O, Jann K 1965 Bacterial lipopolysaccharides. Extraction with phenol-water and further applications of the procedure. In: Whistler R L (ed) Methods in carbohydrate chemistry, vol. V. Academic Press, New York, pp 83-90. 
